\title{
Penetrating cardiac injury: factors affecting outcome
}

\author{
Penetran kalp yaralanmaları: Sağ kalımı etkileyen faktörler
}

\author{
Sedat KAMALI, ${ }^{1}$ Mehmet Timuçin AYDIN, ${ }^{2}$ Arzu AKAN, ${ }^{1}$ Oğuzhan KARATEPE, ${ }^{1}$ \\ Ayhan SARI, ${ }^{1}$ Enis YÜNEY ${ }^{1}$
}

\section{BACKGROUND}

Penetrating cardiac injuries are rare but represent a high mortality. Early recognition of the injury and rapid intervention are necessary. We analyzed the characteristics of patients with penetrating injury and the factors affecting the outcome, including the experience of the general surgeon.

\section{METHODS}

Twenty-three patients suffering penetrating cardiac injury were retrospectively evaluated in the Istanbul Okmeydanı Training and Research Hospital, Department of General Surgery between 1995 and 2009. Patients with no sign of life on admission were excluded.

\section{RESULTS}

All patients were male, and the median age was 25 years. Fifteen patients had left ventricular, 4 had right ventricular and 4 had right atrial injuries; in addition, 2 patients had accompanying intra-abdominal injuries. No coronary vascular injury was reported, and pericardial tamponade did not statistically influence the outcome. Ten of 23 patients suffering of penetrating cardiac injury were lost, and in 6 of the 10 cases, the patient represented the first experience for the operating surgeon.

\section{CONCLUSION}

The characteristics of the penetrating cardiac injuries seen in our institution are consistent with the literature. However, we believe that the surgeon's experience is another prognostic factor. Dedicated level 1 emergency services and trained trauma surgeons are invaluable.

Key Words: Experience; general surgeon; outcome; penetrating cardiac injury.

\section{AMAÇ}

Penetran kalp yaralanmaları nadirdir ancak yüksek mortalite gösterir. Yaralanmalarda erken tanı ve hızlı müdahale gereklidir. Penetran kalp yaralanması ile görülen hastaların karakteristikleri ve bir eğitim hastanesinde acil hizmeti veren genel cerrahların bireysel tecrübeleri dahil bu hastalarda sağkalımı etkileyen faktörler irdelendi.

\section{GEREÇ VE YÖNTEM}

1995-2009 yılları arasında İstanbul Okmeydanı Eğitim ve Araştırma Hastanesi Genel Cerrahi Kliniği'nde penetran kalp yaralanması nedeni ile tedavi edilen 23 hasta retrospektif kohort olarak analiz edildi. Hastaneye ulaştığında hayat belirtisi olmayan hastalar çalışma dışında tutuldu.

\section{BULGULAR}

Hastaların tamamı erkekti. Median yaş 25 yıl olarak saptand. On beş hastada sol 4 hastada sağ ventriküler yaralanma saptandı, 4 hastada sağ atriyal yaralanma görülürken, 2 hastada karın içi yaralanma da eşlik etmekteydi. Hiçbir hastada koroner vasküler yaralanma saptanmadı. Yirmi üç hasta arasindan 10 hasta kaybedildi, bu hastalardan altısının bu tip yaralanmalarda ilk tecrübesini yaşayan cerrahlar tarafından müdahale gördüğü ön plana çıkmıştır. Ayrıca kardiyak tamponad sağ kalımda anlamlı fark oluşturmamıştır.

\section{SONUÇ}

Kurumumuza görülen penetran kardiyak yaralanma özellikleri literatür ile uyumludur. Bu tip yaralanma oranının nispeten az görüldüğü göz önüne alındığında travma cerrahisi eğitimi almış cerrahların ve kapsamlı travma referans merkezlerinin gerekliliği kaçınılmaz olarak gereklidir.

Anahtar Sözcükler: Tecrübe; genel cerrah; penetran kalp yaralanmas1. Genel Cerrahi Kliniği, İstanbul. 
Penetrating cardiac trauma is rare compared to other injuries in urban violence. ${ }^{[1,2]}$ They are infrequent but difficult challenges for the surgeon and represent a very high mortality unless diagnosed and treated in a timely manner. Diagnosis can be easily missed, and expertise in the management is difficult to achieve owing to the relative infrequency $(0.1 \%$ of all trauma admissions). ${ }^{[3]}$ In addition to the stabbing type of violence, the rates of both permitted and unlicensed firearm possession are increasing, and statistics reported almost a two-fold increase in 2007 in Turkey. Improved transport systems and emergency medical services permit an increased number of patients with penetrating cardiac injury to arrive at the hospitals. The surgeons need to be familiar with the possibility of a heart injury, should there be any injury localized to the area between the left anterior axillary and the right mid-clavicular line, as well as between the jugular line and the upper epigastrium.

Clinical presentations of the patients vary according to the wounding mechanism, the time interval before arrival and the time elapsed until entering the operating room (OR), the presence of cardiac tamponade, and the number of associated injuries. Death may be imminent due to cardiac tamponade or exsanguination. Some patients may arrive in extremis with no pulse or detectable blood pressure such that preoperative resuscitation may be of little benefit and treatment requires prompt surgical repair, while others may be in a relatively stable hemodynamic condition and suitable to undergo diagnostic testing.

We planned a retrospective cohort study to evaluate the prognostic factors in the treatment of patients with penetrating cardiac injury and to compare the outcome in such rare injuries with respect to the experience of the general surgeon.

\section{MATERIALS AND METHODS}

Twenty-three patients were operated for penetrating cardiac injury from 1995 to 2009 in Okmeydani Training and Research Hospital, Istanbul. The significance between survival and age, clinical findings at presentation, interval before surgery, type and number of injuries, cardiac massage, and the experience of surgeons in heart injury was investigated via questionnaires to the responsible surgeon and a review of the patients' files retrospectively. Patients with no signs of life on admission were excluded.

The results were analyzed using chi-square and the Pearson correlation tests.

\section{RESULTS}

Between 1995 and 2009, 23 patients were brought to the emergency department of Okmeydani Training and Research Hospital. All patients were male and aged between 17 to 60 years, with a median age of 25 years. There was no correlation between survival and age $(\mathrm{p}=0.55)$. Twenty-two patients had been wounded by stabbing or a similar type of device and one patient suffered a gunshot wound to the pericardial area.

One patient had attempted suicide; the others were victims of homicidal acts. All patients were brought to the hospital with non-emergency vehicles by civilians.

None of the patients arrived in a stable hemodynamic condition, and they were classified on the basis of clinical status at presentation as: (1) hemodynamically unstable with hypotension (systolic blood pressure of $\leq 80 \mathrm{mmHg}$ ) but conscious, and (2) in shock or in extremis with no detectable blood pressure or pulse, and semiconscious to flask. There were 11 patients in the unstable group and 12 patients in the in extremis group. Patients in both groups were assessed primarily in the emergency room (ER) and resuscitation was started. As the hospital facility did not have a cardiologist on call nor echocardiography or ultrasonography devices in the ER, the only possibility for an echocardiographic examination was on the 8th floor in the cardiology ward. The surgeons lacked the experience of performing focused sonography for trauma. As the general condition of the patients dictated, they were transferred directly to the OR, which was within close proximity to the ER $(20 \mathrm{~m})$. No ER thoracotomy was performed as the OR equipment was more available for use. The median systolic blood pressure in the unstable patients (Group 1) was $62.7 \mathrm{mmHg}(40-80$ $\mathrm{mmHg}$, SD 16.1). There were 2 deaths out of 11 patients in the unstable group, and 8 deaths out of 12 patients in the flask group ( $\mathrm{p}=0.01)$. The clinical presentations of the patients carried significance with respect to survival (Table 1). Localization of the wounds on the thorax wall did not demonstrate any relationship with survival $(\mathrm{p}=0.28)$ (Table 2$)$.

All patients underwent left anterolateral thoracotomy initially. Fourteen patients had left ventricular injury, followed by 4 right atrial injuries. Four patients had right ventricular injury. One patient, the gunshot case, had left ventricular and right atrial injuries. The wounds were closed with $2 / 0$ interrupted polypropylene sutures and no bio prosthetic materials were used in cardiorrhaphy. Five patients with left ventricular injury, 3 patients with right atrial injuries and 1 patient with left ventricular injury died. The gunshot patient also died. As the number of the cases is low, we were unable to show any significance regarding the injury site, although 3 out of 4 patients with right atrial injuries died $(\mathrm{p}=0.26)$ (Table 3$)$.

No coronary vascular injuries were reported. The surgeons were also questioned about cardiac tamponade. In 5 cases, no cardiac tamponade was reported, 
Table 1. Survival, surgical experience, cardiac massage, blood pressure cross-tabulation

\begin{tabular}{lllccc}
\hline \multirow{2}{*}{ Surgical experience } & & \multicolumn{2}{c}{ Survival } & \\
\cline { 3 - 4 } & & No (10) & Yes (13) & Total (23) \\
\hline \multirow{2}{*}{ No } & \multirow{2}{*}{ Cardiac massage } & No & 0 & 1 & 1 \\
& & Yes & 6 & 0 & 6 \\
Yes & Cardiac massage & No & 1 & 9 & 10 \\
& & Yes & 3 & 3 & 6 \\
No & \multirow{2}{*}{ Blood pressure } & Not detectable & 6 & 0 & 6 \\
& & Detectable & 0 & 1 & 1 \\
Yes & \multirow{2}{*}{ Blood pressure } & Not detectable & 2 & 4 & 6 \\
& & Detectable & 2 & 8 & 10 \\
\hline
\end{tabular}

but no statistical significance was proven $(p=1.00)$ (Table 4).

When the duration of time that elapsed in the ER was compared, 5 patients were resuscitated for 15 minutes or less and 1 was lost in the OR. However, an intervention period of more than 15 minutes before the OR also had no correlation with survival $(\mathrm{p}=0.33)$ (Table 4). Patients who required per-operative cardiac massage demonstrated a lower survival rate; 9 of 12 patients died $(\mathrm{p}=0.003)$ (Table 1).

In summary, 10 of 23 patients died due to penetrating cardiac injuries. The results were re-evaluated comparing the experience of the operating surgeons. Seven cases were operated by surgeons whose sole experience in cardiac injuries was that case only and 6 of them were lost. On the other hand, the surgeons with operative experience in cardiac injury on more than one case operated on 16 patients and 12 of these patients survived $(\mathrm{p}=0.01)$. The most experienced among the surgeons had operated on three patients.
Two patients had extrathoracic injuries. One patient had gastric and the other had left colonic injury; both patients had accompanying penetrating diaphragmatic injuries. Extrathoracic injuries did not affect survival $(\mathrm{p}=0.71)$ (Table 4).

\section{DISCUSSION}

Penetrating cardiac injuries represent a very difficult challenge for the general surgeon working in usual emergency departments. They are rare encounters in the ER and require quick decision-making and timely surgical intervention.

In 1983, Feliciano et al. ${ }^{[1]}$ described a one-year experience of cardiac injuries in a single institution consisting of 48 patients. A 30-year experience of cardiac injuries from the same institution consisting of 539 patients (18 cardiac injuries per year) was presented by Mattox and associates in 1989. ${ }^{[2]}$ A recent review by Assensio et al. ${ }^{[3]}$ that focused on the National Trauma Data Bank (NTDB) of the American College of

Table 2. Trauma localization, survival, surgical experience cross-tabulation

\begin{tabular}{|c|c|c|c|c|c|c|c|c|c|c|c|c|c|c|}
\hline \multicolumn{3}{|c|}{ Surgical experience } & \multicolumn{12}{|c|}{ Trauma localization } \\
\hline & & & 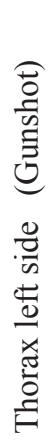 & 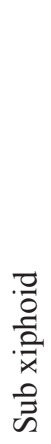 & 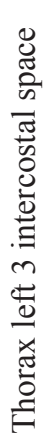 & 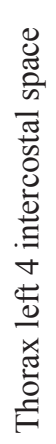 & 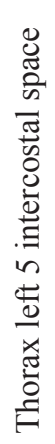 & 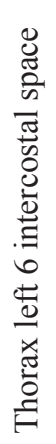 & 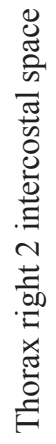 & 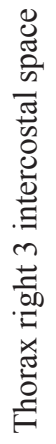 & 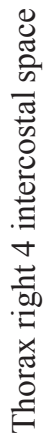 & 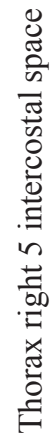 & 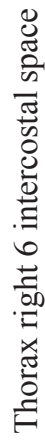 & $\underset{\tilde{O}}{\tilde{0}}$ \\
\hline \multirow[t]{2}{*}{ No } & Survival & No & 0 & 0 & 0 & 2 & 1 & 1 & 0 & 1 & 0 & 1 & 0 & 6 \\
\hline & & Yes & 0 & 1 & 0 & 0 & 0 & 0 & 0 & 0 & 0 & 0 & 0 & 1 \\
\hline \multirow[t]{2}{*}{ Yes } & Survival & No & 1 & 0 & 1 & 1 & 0 & 0 & 0 & 1 & 0 & 0 & 0 & 4 \\
\hline & & Yes & 0 & 3 & 1 & 1 & 3 & 1 & 1 & 0 & 1 & 0 & 1 & 12 \\
\hline
\end{tabular}


Table 3. Survival, injury site, experience cross-tabulation

\begin{tabular}{lllccccc}
\hline \multicolumn{2}{l}{ Surgical experience } & \multicolumn{4}{c}{ Cardiac injury site } \\
\cline { 3 - 7 } & & Left ventricle & Right atrium & Right ventricle & Atrium \& ventricle & Total \\
\hline \multirow{2}{*}{ No } & \multirow{2}{*}{ Survival } & No & 3 & 2 & 1 & 0 & 6 \\
& & Yes & 1 & 0 & 0 & 0 & 1 \\
& Survival & No & 2 & 1 & 0 & 1 & 4 \\
& & Yes & 8 & 1 & 3 & 0 & 12 \\
\hline
\end{tabular}

Surgeons identified 2016 patients sustaining penetrating cardiac injuries, with a nationwide incidence of $0.016 \%$ for these injuries. All the data thus far indicate that penetrating cardiac injuries are indeed rare.

The number and etiology of penetrating cardiac injuries reflect the society in which they occur. In the United States, where firearms are easier to obtain by civilians, the majority of penetrating cardiac injuries are due to gunshot wounds (slightly more than $60 \%$ ). ${ }^{[3]}$ Although the number of the people with individual firearms is increasing in Turkey, stabbing- type penetrating injuries are more frequent in this country, similar to the early reports from South Africa and China. ${ }^{[4-8]}$ Owing to the very nature of the injury, it was reported that up to $90 \%$ of the victims with penetrating cardiac wounds die before reaching the hospital. Although there is no trauma data bank in Turkey, we believe that most of the patients with firearm injuries to the heart are lost before their arrival to the ER. ${ }^{[9,10]}$

The surgeon should be familiar with the anatomic properties of the heart. The boundaries of the precordium are defined by the surface anatomy of the heart. In the normal individual, about one-third of the heart lies to the right of the midline and two-thirds to the left. The right cardiac border extends from the 3 rd to the 6th costal cartilage just lateral to the sternum. The left border lies between the 2ndcostal cartilage 2 $\mathrm{cm}$ left of the sternum and the cardiac apex at the 5th left intercostal space in the mid-clavicular line. ${ }^{[11]}$ The term "cardiac box" can be used as a crude simplification, and refers to the rectangular area between the two mid-clavicular lines laterally and clavicles superiorly to costal margins inferiorly. Most of the anterior surface of the heart is made up by the ventricles. The right ventricle makes up the majority of the anterior sternocostal surface of the heart and it is more prone to injuries than the left atrium, which is smaller and almost an entirely posterior chamber. ${ }^{[11]}$ Because of the high pressure system in the left side of the heart, injuries to the left ventricle are more lethal. The frequency of ventricular injuries in metachronous reports varies from $37 \%$ to $67 \%$ (43\% right ventricle, $34 \%$ left ventricle). ${ }^{[3-5,12]}$ Right atrial injuries appear to occur with a greater frequency than the left atrium, ranging from $5 \%$ to $20 \%$; the most recessed chamber of the heart is injured in $2 \%-12 \%$ of the cases. ${ }^{[3,12-15]}$

Although the patients in this report possessed a highly suggestive representation of cardiac injury (pericardial stabbing on anterior chest in the "cardiac box", hypotension, shock), the clinical manifestations of cardiac injuries may vary from a stable hemodynamic condition to a rapid cardiovascular collapse. No blood pressure or pulse, absence of cardiac rhythm, dilated and fixed pupils, and no motion in extremities are poor prognostic factors. ${ }^{[3,13-17]}$

The greatest danger is missing the diagnosis.

Table 4. Survival, surgical experience, time, other trauma, cardiac tamponade cross-tabulation

\begin{tabular}{|c|c|c|c|c|c|}
\hline \multicolumn{3}{|c|}{ Surgical experience } & \multicolumn{2}{|c|}{ Survival } & \multirow[b]{2}{*}{ Total (23) } \\
\hline & & & No (10) & Yes (13) & \\
\hline \multirow{2}{*}{ No } & Time & $>15$ minutes & 5 & 1 & 6 \\
\hline & & $<15$ minutes & 1 & 0 & 1 \\
\hline \multirow[t]{2}{*}{ Yes } & Time & $>15$ minutes & 4 & 8 & 12 \\
\hline & & $<15$ minutes & 0 & 4 & 4 \\
\hline \multirow[t]{2}{*}{ No } & Other trauma & No & 6 & 1 & 7 \\
\hline & & Yes & 0 & 0 & 0 \\
\hline \multirow[t]{2}{*}{ Yes } & Other trauma & No & 3 & 10 & 13 \\
\hline & & Yes & 1 & 2 & 3 \\
\hline \multirow[t]{2}{*}{ No } & Tamponade & No & 1 & 0 & 1 \\
\hline & & Yes & 5 & 1 & 6 \\
\hline \multirow[t]{2}{*}{ Yes } & Tamponade & No & 1 & 3 & 4 \\
\hline & & Yes & 3 & 9 & 12 \\
\hline
\end{tabular}


Beck's triad - distant heart sounds, jugular venous distension, hypotension - and Kussmaul's sign - jugular venous distension on inspiration - are classical signs of pericardial tamponade, but they are reported in only $10 \%$ of the cases. ${ }^{[3,12]}$ Non-specific signs of shock such as hypotension, agitation, tachypnea, diaphoresis, and cool extremities in a patient with anterior thoracal injury should alert the physician to the possibility of cardiac involvement. Chest X-ray may be misleading since the acute cardiac tamponade may not enlarge the cardiac silhouette. Signs of other thoracic injuries should also be checked, such as pneumo- or hemothoraces. Focused assessment by sonography in trauma (FAST) is currently the more frequently used tool. ${ }^{[11]}$ It is a rapid, non-invasive and repeatable tool, but not available in every emergency department, as was the case in this report. A positive FAST scan provides an echo-free area between the echogenic inner (epicardium) and outer leaves of the pericardium with almost $100 \%$ sensitivity, specificity and accuracy if performed by experienced staff in selected patients (not morbidly obese, no subcutaneous emphysema, and without a very narrow subcostal area) (Fig. 1). ${ }^{[11,18]}$ Thus, the main caveat is that it is both operator- and patient-dependent but still has largely supplanted the pericardial window in the diagnosis. ${ }^{[11,12,18]}$ As pericardiocentesis has high false-positive and -negative rates in the diagnosis of cardiac tamponade, it is generally not recommended.

Initially, there may be a beneficial effect of the pericardial tamponade by limiting the hemorrhage into the thoracic cavity, but a sudden surge of blood increases the pressure within the pericardium above the level of the filling pressure of the right ventricle first. Then, the left ventricular filling becomes compromised, with a final result of decreased stroke volume and cardiac output. This, in turn, increases the cardiac workload

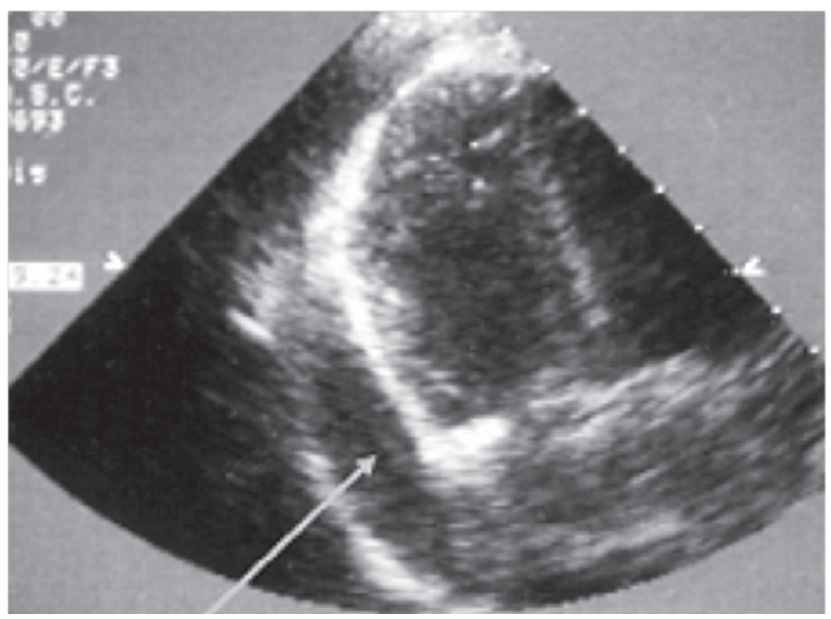

Fig. 1. Arrow indicating a hypoechogenic blood accumulation between two echogenic leaves of the pericardium (cardiac tamponade). with increased coronary oxygen demand to a point where the heart fails to pump..$^{[3,11,12]}$ In a retrospective review of 100 consecutive patients with penetrating cardiac injury, Moreno et al. ${ }^{[15]}$ suggested a protective effect of the cardiac tamponade by reporting 73\% (with tamponade) versus 11\% (without tamponade) survival. On the other hand, Asensio et al. ${ }^{[14,16]}$ in a prospective study of predictors of the outcome after penetrating cardiac injury could not confirm a beneficial effect of the cardiac tamponade. In our report of 23 patients, we could not show a beneficial effect of tamponade.

Emergency room (ER) thoracotomy is reported as a life-saving procedure in a select group of patients, but it is a matter of controversy in the literature. It is a frequent disclosure that ER thoracotomy is of benefit in penetrating precordial injury victims in whom a traumatic arrest develops after previously witnessed pre-hospital or in-hospital cardiac activity and who suffer from unresponsive hypotension. ${ }^{[11,19]}$ No patient in this report underwent an ER thoracotomy. Departmental policies of the institution suggested that the correct surgical equipment should be preserved in the $\mathrm{OR}$, which is in close proximity.

The ventricular injuries can be controlled by finger pressure at first. Then, the wounds are closed by simple interrupted or horizontal mattress sutures using $2 / 0$ monofilament Prolene materials. It is also possible to repair the laceration with running sutures. Care should be given to the coronary vessels; otherwise, acute coronary infarction on the operating table should be anticipated. ${ }^{[3,6,7,13-15]}$ Atrial injuries can be controlled by placing a vascular clamp to control the hemorrhage and they can then be sutured with running 2/0 Prolene. The surgeon should pay attention to the thinner walls of the atria, which can easily be torn, thereby enlarging the laceration. ${ }^{[3,17,20]}$

In addition to all the factors that may affect the outcome of the penetrating cardiac injuries that have been identified thus far, we strongly believe that the experience of the general surgeon is a major determinant in the evaluation and treatment of the patient as well as the outcome, especially if the facility lacks a cardiovascular surgery unit. Concerning penetrating cardiac trauma, the number of cases per year and per institution is not frequent. In the United States, the nationwide incidence is $0.016 \%{ }^{[3]}$ Furthermore, a post-mortem study in a city that has a much smaller population than the metropolitan city of Istanbul indicated that only $3.5 \%$ of the penetrating cardiac injury cases were admitted to the hospitals. ${ }^{[10]}$ We lost six of seven patients when the surgeon had no previous experience in penetrating cardiac injury. The general surgeon is usually much more experienced in abdominal procedures in contrast to thorax procedures, includ- 
ing cardiac surgery. A report from the United States, where trauma surgery is a subspecialty after general surgery training, stated that only $62 \%$ of surgeons had performed an emergency cardiac repair. Since the incidence is rare, timing is very critical; mortality is reported as high even in high-volume centers. As some injuries may require cardiopulmonary bypass surgery, the decision-making by the general surgeon becomes even more difficult. Without proper training of the surgeons in trauma surgery, the learning curve will be greatly prolonged. Although the best prohibitive measure is to prevent any injury if possible, dedicated trauma centers with experienced trauma surgeons cannot be underestimated.

\section{REFERENCES}

1. Feliciano DV, Bitondo CG, Mattox KL, Burch JM, Jordan GL Jr, Beall AC Jr, et al. Civilian trauma in the 1980s. A 1-year experience with 456 vascular and cardiac injuries. Ann Surg 1984;199:717-24.

2. Mattox KL, Feliciano DV, Burch J, Beall AC Jr, Jordan GL Jr, De Bakey ME. Five thousand seven hundred sixty cardiovascular injuries in 4459 patients. Epidemiologic evolution 1958 to 1987. Ann Surg 1989;209:698-707.

3. Asensio JA, Garcia-Nunez LM, Petrone P, Duran D, et al. Penetrating cardiac injuries in America- predictors of outcome in 2016 patients from the national trauma data bank; in preparation As quoted by Asensio JA, et al. Cardiac injuries. In: Asensio JA, Trunkey DD, editors. Current therapy of trauma and surgical critical care. Philadephia: Mosby Elsevier; 2008. p. 304-15.

4. Demetriades D, van der Veen BW. Penetrating injuries of the heart: experience over two years in South Africa. J Trauma 1983;23:1034-41.

5. Gao JM, Gao YH, Wei GB, Liu GL, Tian XY, Hu P, et al. Penetrating cardiac wounds: principles for surgical management. World J Surg 2004;28:1025-9.

6. Günay K, Taviloglu K, Eskioglu E, Ertekin C. The factors affecting mortality in penetrating heart wounds. Ulus Travma Derg 1995;1:47-50.

7. Keçeligil HT, Bahcivan M, Demirağ MK, Celik S, Kol- bakir F. Principles for the treatment of cardiac injuries: a twenty-two year experience. Ulus Travma Acil Cerrahi Derg 2009; 15:171-5.

8. Türkiye'de Bireysel Silahlanmaya'ya İlişkin istatistikler. Umut Foundation, 2007.

9. Campbell NC, Thomson SR, Muckart DJ, Meumann CM, Van Middelkoop I, Botha JB. Review of 1198 cases of penetrating cardiac trauma. Br J Surg 1997;84:1737-40.

10. Fedakar R, Türkmen N, Durak D, Gündoğmuş UN. Fatal traumatic heart wounds: review of 160 autopsy cases. Isr Med Assoc J 2005;7:498-501.

11. Kang N, Hsee L, Rizoli S, Alison P. Penetrating cardiac injury: overcoming the limits set by Nature. Injury 2009;40:91927.

12. Asensio J, Garcia-Nunez L, Wood D, Jurkovich G. Trauma to the heart. In: Feliciano D, Mattox KL, Moore E. editors. Trauma. Mc-Graw Hill; 2008. p 569-8.

13. Wall MJ Jr, Mattox KL, Chen CD, Baldwin JC. Acute management of complex cardiac injuries. J Trauma 1997;42:90512.

14. Asensio JA, Murray J, Demetriades D, Berne J, Cornwell E, Velmahos $G$, et al. Penetrating cardiac injuries: a prospective study of variables predicting outcomes. J Am Coll Surg 1998; 186:24-34.

15. Moreno C, Moore EE, Majure JA, Hopeman AR. Pericardial tamponade: a critical determinant for survival following penetrating cardiac wounds. J Trauma 1986;26:821-5.

16. Asensio JA, Berne JD, Demetriades D, Chan L, Murray J, Falabella A, et al. One hundred five penetrating cardiac injuries: a 2-year prospective evaluation. J Trauma 1998;44:1073-82.

17. Asensio JA, Soto SN, Forno W, Roldan G, Petrone P, Salim A, et al. Penetrating cardiac injuries: a complex challenge. Injury 2001;32:533-43.

18. Rozycki GS, Feliciano DV, Schmidt JA, Cushman JG, Sisley $\mathrm{AC}$, Ingram $\mathrm{W}$, et al. The role of surgeon-performed ultrasound in patients with possible cardiac wounds. Ann Surg 1996;223:737-46.

19. Brohi K. Emergency room thoracotomy. September 2006. Trauma.org web site. Available from URL: http// www.trauma.org/index.php/main/article/361.

20. Tyburski JG, Astra L, Wilson RF, Dente C, Steffes C. Factors affecting prognosis with penetrating wounds of the heart. J Trauma 2000;48:587-91. 